\title{
Evaluation of the anti-diarrheal activity of the leaf extract of Croton macrostachyus Hocsht. ex Del. (Euphorbiaceae) in mice model
}

\author{
Amsalu Degu ${ }^{1 *}$ (D) Ephrem Engidawork ${ }^{2}$ and Workineh Shibeshi ${ }^{2}$
}

\begin{abstract}
Background: Traditional healers in Ethiopia use a wide range of medicinal plants with antidiarrheal properties. Among these, Croton macrostachyus is one such plant claimed to have an antidiarrheal activity in Ethiopian folklore medicine. Previous studies showed that the crude extract is endowed with the claimed property. The present study was undertaken to further the claim by screening different fractions for the said activity so that it could serve as a basis for subsequent studies.

Methods: The fractions were obtained by successive extraction in soxhlet apparatus with solvents of different polarity (chloroform \& methanol) followed by cold maceration of the deposit of the methanol fraction with distilled water. The antidiarrheal activity was evaluated using castor oil induced diarrheal model, charcoal meal test and anti-enteropooling test in mice. The test groups received various doses (300,400, $500 \mathrm{mg} / \mathrm{kg}$ and an additional dose of $1000 \mathrm{mg} / \mathrm{kg}$ for the aqueous fraction) of the fractions, whereas positive controls received either Loperamide (3 mg/ $\mathrm{kg}$ ) or Atropine $(5 \mathrm{mg} / \mathrm{kg})$ and negative controls received vehicle $(10 \mathrm{ml} / \mathrm{kg})$.
\end{abstract}

Results: In the castor oil induced model, the chloroform (at all test doses) and methanol (at $400 \& 500 \mathrm{mg} / \mathrm{kg}$ ) fractions significantly delayed diarrheal onset, decreased stool frequency and weight of feces. The aqueous fraction was however devoid of significant effect at all the tested doses. Chloroform and methanol fractions produced a significant dose dependent decline in the weight and volume of intestinal contents while the aqueous fraction did not have a significant effect. All the fractions produced a significant anti-motility effect either at all doses (chloroform fraction) or at middle and higher doses (methanol and aqueous fractions).

Conclusion: The present study demonstrated that the chloroform and methanol fractions possessed significant anti-diarrheal activity. Nevertheless, the aqueous fraction showed only significant anti-motility effect at the higher dose $(1000 \mathrm{mg} / \mathrm{kg})$ employed in the study.

Keywords: Antidiarrheal activity, Castor oil induced diarrhea, Gastrointestinal transit, Anti-enteropooling, Croton macrostachyus,

\footnotetext{
* Correspondence: amsaludegu@yahoo.com

${ }^{1}$ Department of Pharmacy, College of Medicine and Health Sciences, Ambo

University, P.O, Box 19, Ambo, Ethiopia

Full list of author information is available at the end of the article
} 


\section{Background}

Diarrheal diseases account for one in nine child deaths worldwide, making diarrhea the second leading cause of death among children under the age of five and responsible for killing around 760, 000 children every year $[1,2]$. The global burden of diarrheal incidence and severity of the disease is highest in Southeast Asian and African regions [3], with the highest childhood deaths being reported in Sub-saharan Africa [4]. In Ethiopia, diarrhea disease is a major public healthconcern as it results in high childhood mortality and mortality [5-8].

Herbal medicines cater about $80 \%$ of the health needs of world's population, especially for millions of people in the vast rural areas of developing countries [9, 10]. In Ethiopia, a wide range of medicinal plants have been widely used for the management of diarrhea without scientific investigation of its safety and therapeutic potentials $[11,12]$.

Among these, Croton macrostachyus Hochst.ex Del. (Euphorbiaceae) which is commonly known as broadleaved Croton (English), Bisana (Amharic), Tambuk and Tambush (Tigrigna), and Abnga in Berta ethnic group $[13,14]$ is endowed with a number of ethnomedicinal uses in Ethiopia [12, 13, 15, 16]. Ethnopharmacological studies revealed that hydroalcoholic extracts of C.macrostachyus leaves have promising activity against Neisseria gonorrhoeae [17], Plasmodium berghei [18] and Mycobacterium tuberculosis [19]. It also has analgesic and anti-inflammatory [20], anti-convulsant and sedative [21] and anti-leishmanial activities [22].

In addition, it has previously been demonstrated that the crude leaves extract of C. macrostachyus has remarkable antidiarrhoeal activity in an animal model of diarrhea [41]. However, it is not known which solvent fractions possess antidiarrheal activity. The present study aims to investigate the antidiarrheal activity of the solvent fractions of C.macrostachyus leaves in mice.

\section{Methods}

Drugs and chemicals

Castor oil (Amman Pharmaceutical Industries, Jordan), activated charcoal (Acuro Organics Ltd, New Delhi), Loperamide (Daehwa Pharmaceuticals, Republic of Korea), Atropine sulphate (Lab Renaudin, France), distilled water (Ethiopian Pharmaceutical Manufacturing Factory, Ethiopia), Tween 80 (Atlas Chemical Industries Inc, India), chloroform (Finkem Laboratory Reagent, India), and methanol (Fisher Scientific, UK) were used in the study.

\section{Plant material}

Leaves of C.macrostachyus were collected from Kolfe keranio subcity of Addis Ababa City Administration in October 2013. The plant was authenticated and a voucher specimen (number AD001) was deposited at the
National Herbarium of Addis Ababa University for future reference. The leaves were washed using distilled water, dried at room temperature under shade for 14 days and then pulverized to coarse powder using mortar and pestle.

\section{Experimental animals}

Healthy Swiss albino mice of either sex, weighing 20-30 g and aged 6-8 weeks were used for the experiment. The animals were obtained from Ethiopian Public Health Institute and School of Pharmacy, Addis Ababa University and kept in plastic cages at room temperature and on a $12 \mathrm{~h}$ light-dark cycle with free access to pellet food and water ad libitum. The animals were acclimatized to laboratory condition for 1 week prior to the experiments [23]. All studies were conducted in accordance with the guideline for the care and use of laboratory animals [24].

\section{Solvent fractionation}

Two hundred gm dry powder of the plant material was subjected to successive soxhlet extraction with solvents of different polarity (chloroform and methanol) followed by cold maceration with water. First, $50 \mathrm{mg}$ of the powdered plant material was placed in the extraction chamber of the Soxhlet apparatus. The extracting solvent (chloroform) in the flask was heated until clear liquid contents of the chamber siphoned into the solvent flask. Each time $50 \mathrm{mg}$ of the powdered plant material was extracted with $200 \mathrm{ml}$ of solvent in the soxhlet extraction process [25]. The chloroform fraction was then filtered with Whatman No. 1 filter paper and concentrated using rotary evaporator (Buchi labortechnik AG, Switzerland) under reduced pressure set at $40{ }^{\circ} \mathrm{C}$ followed by oven at room temperature for $12 \mathrm{~h}$ [26]. The residue was collected and dried at room temperature to remove chloroform.

The plant material was then dried and extracted using methanol following the same procedure as described before to get the methanol fraction. Finally, the residue of methanol fraction was collected and dried at room temperature. Then, the whole dried residue was cold macerated in an Erlenmeyer flask with distilled water and allowed to stand at room temperature for a period of $72 \mathrm{~h}$ with occasional shaking using mini orbital shaker (Bibby scientific limited stone Staffordshire, SI150SA, UK). It was then filtered two times with gauze then through whatman filter paper (NO.1). The residue was re- macerated two times for a total of 6 days in order to obtain a better yield. The marc was pressed, and the combined liquid was clarified by filtration and then the filtrate was freeze dried in a lyophilizer (Operan, Korea vacuum limited, Korea) to remove water. After drying, percentage yield of all fractions were determined and the yield was of 4.7, 5.6, and $3.5 \%$ for the chloroform, 
methanol and aqueous fractions, respectively. The chloroform and methanol fractions were reconstituted in $2 \%$ Tween- 80 , while the aqueous fraction was reconstituted in distilled water.

\section{Grouping and dosing}

The study was conducted using 30 mice for each fraction. The mice were randomly assigned into three treatment groups and two controls, six mice per group for each fraction. Negative controls were treated with the vehicle used for reconstitution $(2 \% \mathrm{v} / \mathrm{v}$ Tween 80 for the chloroform and methanol fractions or distilled water for the aqueous fraction) orally using oral gavage. The second group was assigned as positive control and treated with standard drugs $(3 \mathrm{mg} / \mathrm{kg}$ Loperamide orally for anti-enteropooling test \& castor oil induced diarrhea, $5 \mathrm{mg} / \mathrm{kg}$ Atropine sulphate intraperitoneally for charcoal meal test). Treatment groups were treated with various doses of the fractions $(300,400,500 \mathrm{mg} / \mathrm{kg}$ for the chloroform and methanol fractions, and an additional dose of $1000 \mathrm{mg} / \mathrm{kg}$ for the aqueous fraction). Doses were selected based on acute toxicity studies. The fractions were reconstituted with the respective vehicles during the day of experiment and administered orally using oral gavage.

\section{Determination of antidiarrheal activity Castor oil induced Diarrhea}

Swiss albino mice of either sex were fasted for $18 \mathrm{~h}$ with free access to water and randomly allocated and treated as described under grouping and dosing. One hour after administration, all animals were given $0.5 \mathrm{ml}$ of castor oil orally and individually placed in cages in which the floor was lined with transparent paper and changed every hour. During an observation period of $4 \mathrm{~h}$, the time of onset of diarrhea, frequency of defecation and weight of feces excreted by the animals was recorded [23]. The percentage of diarrheal inhibition was determined according to the following formula [27, 28].

$\%$ of inhibition $=\frac{\text { Average number of WFC }- \text { Average number of WFT }}{\text { Average number of WFC }} * 100$

Where, WFC = average number of wet feces in control group and WFT = average number of wet feces in test group.

Calculations were made for the delay in diarrhoeal onset and purging index by comparing with the control group. The in vivo anti-diarhhoeal index (ADI) was then expressed according to the formula [29] described below.

Invivoantidiarrheal index $(A D I)=\sqrt[3]{D \text { freq } \times \text { Gmeq } \times \text { Pfreq }}$

Where: Dfreq = Delay in defecation time or diarrheal onset (in \% of control), Gmeq = Gut meal travel reduction (in \% of control) and Pfreq=purging frequency as number of wet stool reduction (in \% of control).

\section{Charcoal meal (gastrointestinal motility) test}

Mice of either sex were fasted for $18 \mathrm{~h}$ with free access to water and divided and treated according to their respective groupings $1 \mathrm{~h}$ before oral administration of $0.5 \mathrm{ml}$ castor oil. $1 \mathrm{ml}$ of a marker (5\% charcoal suspension in $2 \%$ Tween 80 ) was administered orally $1 \mathrm{~h}$ after castor oil treatment. The animals were then sacrificed $1 \mathrm{~h}$ after administration of the marker and the small intestine was dissected out from pylorus to caecum. The distance travelled by charcoal meal from the pylorus was measured [30]. Then, the percentage of inhibition and Peristalsis index was expressed using the following formula $[28,29,31]$.

$$
\text { Percentage of inhibition }=\frac{\mathrm{A}-\mathrm{B}}{\mathrm{A}} * 100
$$

where $\mathrm{A}$ is the distance $(\mathrm{cm})$ moved by the charcoal in the control group, and B is the distance $(\mathrm{cm})$ moved by the charcoal in the treated group.

$$
\text { Peristalsis index }=\frac{\text { mean distance traveled by charcoal meal }}{\text { mean length of small intestine }} * 100
$$

\section{Anti-enteropooling test}

Intraluminal fluid accumulation was determined using the method described by Islam et al. [32]. Animals of either sex were deprived both food and water for $18 \mathrm{~h}$, and grouped and treated as described under grouping dosing. After $1 \mathrm{~h}, 0.5 \mathrm{ml}$ of castor oil was administered orally. $1 \mathrm{~h}$ later, the mice were sacrificed by cervical dislocation and the small intestine was then dissected out and weighed. After which, intestinal contents were collected by milking into a graduated tube and the volume was measured. The intestine was reweighed and the difference between the full and the empty intestine was calculated [32]. Finally, percentage of reduction of intestinal secretion and weight of intestinal contents was determined using the following formula [28].

$$
\text { Mean Percentage inhibition }=\frac{\text { MVICC-MVICT }}{\text { MVICC }} * 100
$$

Where, MVICC is the mean volume of the intestinal content of the control group while MVICT is the mean volume of the intestinal content of the test group.

Mean percentage inhibition of intestinal content weight $=\frac{A-B}{A} * 100$

Where $\mathrm{A}$ is the mean weight of intestinal content of the control and $\mathrm{B}$ is the mean weight of intestine content of the test group. 


\section{Preliminary phytochemical screening}

The qualitative phytochemical investigations of the chloroform, absolute methanol and aqueous fractions of C.macrostachyus leaves were carried out using standard tests like Mayer's test for alkaloids, Liberman -Burchard test for steroids, Salkowski test for terpenoids, Keller-Kilani test for glycosides and Ferric chloride test for tannins [33].

\section{Test for terpenoids (Salkowski test)}

To $0.5 \mathrm{~g}$ of each solvent fraction of C.macrostachyus leaves, $2 \mathrm{ml}$ of chloroform was added. Then, $3 \mathrm{ml}$ concentrated sulfuric acid was carefully added to form a layer. A reddish brown coloration of the interface indicates the presence of terpenoids.

\section{Test for Saponins}

To $0.5 \mathrm{~g}$ of each fraction, $5 \mathrm{ml}$ of distilled water was added in a test tube. Then, the solution was shaken vigorously and observed for a stable persistent froth. Formation of froth indicates the presence of Saponins.

\section{Test for tannins}

About $0.5 \mathrm{~g}$ of each fraction was boiled in $10 \mathrm{ml}$ of water in a test tube and then filtered. A few drops of $0.1 \%$ ferric chloride were added. A brownish green or a blue-black precipitate indicated the presence of tannins.

\section{Test for flavonoids}

About $10 \mathrm{ml}$ of ethyl acetate was added to $0.2 \mathrm{~g}$ of each fraction and heated on water bath for $3 \mathrm{~min}$. The mixture was cooled and filtered. Then, About $4 \mathrm{ml}$ of the filtrate was shaken with $1 \mathrm{ml}$ of dilute ammonia solution. The layers were allowed to separate and the yellow color in the ammoniacal layer indicated the presence of Flavonoids.

\section{Test for cardiac glycosides (Keller-Killiani test)}

To $0.5 \mathrm{~g}$ of each fraction diluted to $5 \mathrm{ml}$ in water was added $2 \mathrm{ml}$ of glacial acetic acid containing one drop of ferric chloride solution. This was underlayed with $1 \mathrm{ml}$ of concentrated Sulfuric acid. A brown ring at the interface indicated the presence of a deoxysugar characteristic of cardenolides. A violet ring may appear below the brown ring, while in the acetic acid layer a greenish ring may form just above the brown ring and gradually spread throughout this layer.

\section{Test for steroids}

Two $\mathrm{ml}$ of acetic anhydride was added to $0.5 \mathrm{~g}$ fraction of each sample with $2 \mathrm{ml}$ sulfuric acid. The color changed from violet to blue or green in some samples indicating the presence of steroids.

\section{Test for alkaloids}

$0.5 \mathrm{~g}$ of extract was diluted to $10 \mathrm{ml}$ with acid alcohol, boiled, and filtered. To $5 \mathrm{ml}$ of the filtrate, $2 \mathrm{ml}$ of dilute ammonia and $5 \mathrm{ml}$ of chloroform was added and shaken gently to extract the alkaloidal base. The chloroform layer was extracted with $10 \mathrm{ml}$ of acetic acid. This was divided into two portions. Mayer's reagent was added to one portion and Draggendorff's reagent to the other. The formation of a cream (with Mayer's reagent) or reddish brown precipitate (with Draggendorff's reagent) was regarded as positive for the presence of alkaloids.

\section{Oral acute toxicity}

Two groups of six female Swiss albino mice were used for each fraction. After being fasted for $2 \mathrm{~h}$, mice in the first group were given $2 \mathrm{~g} / \mathrm{kg}$ and the second group $5 \mathrm{~g} /$ $\mathrm{kg}$ of each fraction orally and observed for any signs of toxicity daily for 14 days to assess safety of the extract. Animals were observed for gross changes such as loss of appetite, hair erection, lacrimation, tremors, convulsions, salivation, diarrhoea, mortality and other signs of overt toxicity [34].

\section{Statistical analysis}

Data are expressed as mean \pm standard error of the mean (SEM) and analyzed using the Statistical Package for the Social Sciences (SPSS), version 16.0 software. Difference between group means was analyzed with one way analysis of variance (ANOVA) followed by Tukey post Hoc test. $P<0.05$ was considered as statistically significant.

\section{Results}

Oral acute toxicity study

The acute toxicity study indicated that the fraction caused no mortality in both doses $(2$ and $5 \mathrm{~g} / \mathrm{kg}$ ) within the first $24 \mathrm{~h}$ as well as for the following 14 days. Physical and behavioral observations of the experimental mice also revealed no visible signs of overt toxicity like lacrimation, loss of appetite, tremors, hair erection, salivation, diarrhea and the like. This suggests that LD50 of the extract is greater than $5 \mathrm{~g} / \mathrm{kg}$.

\section{Effects on castor oil- induced diarrhea in mice}

In the castor oil-induced diarrheal model (Table 1), the chloroform (at all doses tested) and methanol fraction (at $400 \& 500 \mathrm{mg} / \mathrm{kg}$ ) of C. macrostachyus leaves significantly delayed the time of diarrheal onset and stool frequency in a dose-dependent manner. In addition, at all the tested doses, the chloroform fraction produced comparable effect with the standard drug, Loperamide $(81.5 \%)$. On the contrary, the aqueous fraction was devoid of significant anti-diarrheal activity on castor oil induced diarrhea at all tested doses as compared with the negative control (Table 1). 
Table 1 Effect of the fractions of Croton macrostachyus leaves on castor oil induced diarrheal model in mice

\begin{tabular}{|c|c|c|c|c|c|}
\hline Group & $\begin{array}{l}\text { Onset time of } \\
\text { diarrhea (min) }\end{array}$ & $\begin{array}{l}\text { Total \# of wet } \\
\text { feces in } 4 \mathrm{~h}\end{array}$ & Total \# of feces & Total weight of feces(gm) & $\begin{array}{l}\% \text { inhibition } \\
\text { of defecation }\end{array}$ \\
\hline Control & $76 \pm 16.71$ & $4.5 \pm 0.72$ & $4.67 \pm 0.80$ & $0.82 \pm 0.19$ & - \\
\hline Loperamide 3 mg/kg & $167.83 \pm 25.62^{\mathrm{a} *}$ & $0.833 \pm 0.31^{a_{* * *}}$ & $1.83 \pm 0.65^{a_{*}}$ & $0.17 \pm 0.044^{\mathrm{a} *}$ & 81.49 \\
\hline CF300mg/kg & $169.83 \pm 22.78^{\mathrm{a} *}$ & $1.33 \pm 0.42^{\mathrm{a} * * *}$ & $1.83 \pm 0.65^{\mathrm{a}_{*}}$ & $0.29 \pm 0.14^{\mathrm{a} *}$ & 70.37 \\
\hline CF400mg/kg & $217.50 \pm 22.50^{\mathrm{a} * * *}$ & $0.33 \pm 0.33^{\mathrm{a} * * *}$ & $0.83 \pm 0.31^{a * *}$ & $0.14 \pm 0.13^{\mathrm{a} *}$ & 92.59 \\
\hline CF500mg/kg & $238.33 \pm 1.67^{a * * *}$ & $0.17 \pm 0.17^{a * * *}$ & $0.167 \pm 0.166^{a * * *}$ & $0.10 \pm 0.10^{a *}$ & 96.296 \\
\hline Control & $82.5 \pm 19.96$ & $4.67 \pm 0.49$ & $5.33 \pm 0.42$ & $0.83 \pm 0.22$ & -— \\
\hline Loperamide 3 mg/kg & $167.83 \pm 25.62^{\mathrm{a} *}$ & $0.833 \pm 0.31^{a * * *}$ & $1.83 \pm 0.65^{\mathrm{a} *}$ & $0.17 \pm 0.044^{\mathrm{a} *}$ & 82.16 \\
\hline MF300mg/kg & $143.5 \pm 25.54$ & $2.5 \pm 0.56$ & $3.83 \pm 0.48$ & $0.37 \pm 0.15$ & 46.47 \\
\hline MF400mg/kg & $186.33 \pm 22.19^{a *}$ & $1.17 \pm 0.48^{\mathrm{a**}}$ & $2.50 \pm 0.85^{a *}$ & $0.114 \pm 0.05^{a *}$ & 74.95 \\
\hline MF500mg/kg & $191.33 \pm 30.62^{\mathrm{a} *}$ & $0.83 \pm 0.48^{\mathrm{a***}}$ & $1.17 \pm 0.60^{a *}$ & $0.11 \pm 0.06^{\mathrm{a} *}$ & 82.23 \\
\hline Control & $42.50 \pm 4.16$ & $7.00 \pm 0.89$ & $6.67 \pm 0.80$ & $0.72 \pm 0.13$ & -—— \\
\hline Loperamide $3 \mathrm{mg} / \mathrm{kg}$ & $120.50 \pm 28.07^{a *}$ & $1.50 \pm 0.22^{\mathrm{a}_{* *} c_{* *} \mathrm{~d}_{* *} * * f_{*}}$ & $2.00 \pm 0.37^{a * c_{*} d_{*} e_{*}}$ & $0.15 \pm 0.07^{a_{*} c_{* * *} d_{* *} e_{* *}}$ & 78.57 \\
\hline AF300mg/kg & $54.17 \pm 8.60^{h_{* * * * *}}$ & $6.83 \pm 0.83^{b_{* *} g_{* * * h * * * \mid * * *}}$ & $8.17 \pm 1.66^{b * g_{* * *} h_{* * * * * * * *}}$ & $0.71 \pm 0.096^{b * * g_{* * *} h_{* * * * * * *}}$ & 2.43 \\
\hline AF400mg/kg & $55.00 \pm 8.79^{h * * * * *}$ & $6.67 \pm 1.05^{\mathrm{b} * * g_{* * *} h_{* * * 1 * * *}}$ & $7.33 \pm 0.99^{b * g * * * h * * * \mid * * *}$ & $0.69 \pm 0.21^{\left.b * * g * * * h * * *\right|_{* * *}}$ & 4.71 \\
\hline AF500mg/kg & $60.67 \pm 2.58^{h_{* * 1 * *}}$ & $6.50 \pm 1.09^{\mathrm{b} * g_{* * * h} h_{* * *} \mid * * *}$ & $7.17 \pm 1.11^{b * g * * * h * * * l_{* * *}}$ & $0.68 \pm 0.06^{b * g_{* * * h * * * 1 * * *}}$ & 7.14 \\
\hline AF1000mg/kg & $82.17 \pm 28.13^{h * * \mid * *}$ & $6.17 \pm 1.30^{b * g * * * h * * * \mid * * *}$ & $6.33 \pm 1.17^{b * g * * * h * * * \mid * * *}$ & $0.56 \pm 0.11$ & 11.86 \\
\hline
\end{tabular}

Values are expressed as Mean \pm S.E.M $(n=6)$, analysis was performed with One-Way ANOVA followed by Tukey test, ${ }^{\text {a }}$ compared to control, ${ }^{\mathrm{b}}$ to standard drug, ${ }^{\mathrm{c}}$ to

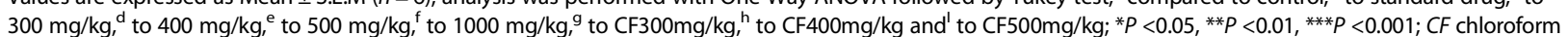
fraction, MF methanol fraction, $A F$ aqueous fraction. Negative controls were treated with the vehicle used for reconstitution ( $2 \% \mathrm{v} / \mathrm{v}$ Tween 80 for the chloroform and methanol fractions or distilled water for the aqueous fraction) orally

\section{Effects on castor oil- induced enteropooling in mice}

In gastrointestinal enteropooling test, the chloroform and methanol fractions of $C$. macrostachyus leaves reduced the volume of intestinal fluid and weight of the intestinal contents significantly in a dose-dependent manner. Maximum percentage inhibition of the volume of intestinal contents was observed at $500 \mathrm{mg} / \mathrm{kg}$, being $76.1 \%(p<0.01)$ and $75.3 \%(P<0.01)$ for chloroform and methanol fractions, respectively. Similarly, the uppermost reduction for the weight of intestinal contents was observed at $500 \mathrm{mg} / \mathrm{kg}$ for both chloroform and methanol fractions. However, there was no statistically significant difference in the volume of intestinal fluid and weight of intestinal contents when all doses of the chloroform and methanol fractions were compared with Loperamide. On the contrary, the aqueous fraction did not show significant inhibitory effect on the volume and weight of intestinal fluid as compared with the negative control (Table 2).

\section{Effects on castor oil- induced intestinal transit in mice}

The chloroform fraction significantly inhibited gastrointestinal transit time of charcoal meal at $300(25.5 \%, p<0.05)$, $400(43.4 \%, p<0.01)$, and $500(52.4 \%, p<0.01) \mathrm{mg} / \mathrm{kg}$ in comparison to the control. On the other hand, the methanol fraction of $C$. macrostachyus leaves had statistically significant inhibitory effect $(56.1 \%, p<0.001)$ on gastrointestinal transit time of charcoal meal only at the dose of
$500 \mathrm{mg} / \mathrm{kg}$. Interestingly, compared to the control, the aqueous fraction showed significant inhibition of gastrointestinal transit $(44.3 \%, p<0.05)$ of charcoal meal at the dose of $1000 \mathrm{mg} / \mathrm{kg}$ (Table 3).

\section{In vivo anti-diarrheal index}

There was a dose dependent increase in vivo antidiarrheal index in chloroform and methanol fractions of C. macrostachyus leaves. The highest anti-diarrheal index was observed at the maximum dose of each fraction. However, amongst all solvent fractions of C. macrostachyus leaves, the chloroform fraction showed the highest anti-diarrheal index at $500 \mathrm{mg} / \mathrm{kg}$ (Fig. 1).

\section{Preliminary phytochemical screening}

Phytochemical screening of solvent fractions C. macrostachyus leaves revealed that the presence of alkaloids, steroids and Terpenoids in the chloroform fraction. On the other hand, the methanol fraction possessed alkaloids, Saponins, tannins, flavonoids, and cardiac glycosides whereas the aqueous fraction was found to contain Saponins, Tannins and alkaloids (Table 4).

\section{Discussion}

The use of castor oil as diarrhea inducer is well documented [25, 35, 36]. Its active metabolite, ricinoleic acid, is responsible for the diarrhea inducing properties and is 
Table 2 Effect of the fractions of Croton macrostachyus leaves on castor oil induced enteropooling in mice

\begin{tabular}{|c|c|c|c|c|}
\hline Dose administered & $\begin{array}{l}\text { Volume of } \\
\text { intestinal content }(\mathrm{ml})\end{array}$ & $\%$ of inhibition & $\begin{array}{l}\text { Mean weight of } \\
\text { intestinal content }(\mathrm{gm})\end{array}$ & $\%$ of inhibition \\
\hline Control & $0.67 \pm 0.21$ & ーーーーー & $0.78 \pm 0.16$ & ーーーーー \\
\hline Loperamide 3 mg/kg & $0.12 \pm 0.08^{\mathrm{a}_{* *}}$ & 82.1 & $0.21 \pm 0.08^{\mathrm{a}_{* *}}$ & 73.08 \\
\hline CF300mg/kg & $0.18 \pm 0.054^{\mathrm{a} *}$ & 73.13 & $0.27 \pm 0.09^{a_{* *}}$ & 65.38 \\
\hline CF400mg/kg & $0.17 \pm 0.03^{\mathrm{a} *}$ & 74.6 & $0.269 \pm 0.06^{\mathrm{a} * *}$ & 65.51 \\
\hline CF500mg/kg & $0.16 \pm 0.04^{\mathrm{a} * *}$ & 76.12 & $0.248 \pm 0.04^{a * *}$ & 68.21 \\
\hline Control & $0.77 \pm 0.17$ & -—-- - & $0.83 \pm 0.2$ & -——-— \\
\hline Loperamide 3 mg/kg & $0.12 \pm 0.08^{\mathrm{a} * * *}$ & 84.41 & $0.21 \pm 0.078^{\mathrm{a} * *}$ & 74.70 \\
\hline MF300mg/kg & $0.30 \pm 0.05^{\mathrm{a} *}$ & 61.04 & $0.36 \pm 0.11^{\mathrm{a} *}$ & 56.63 \\
\hline MF400mg/kg & $0.20 \pm 0.04^{\mathrm{a} * *}$ & 74.03 & $0.31 \pm 0.04^{\mathrm{a} *}$ & 62.65 \\
\hline MF500mg/kg & $0.19 \pm 0.02^{a_{* *}}$ & 75.32 & $0.29 \pm 0.03^{a_{*}}$ & 65.06 \\
\hline Control & $0.47 \pm 0.06$ & ーーーーー & $0.45 \pm 0.07$ & -—— \\
\hline Loperamide 3 mg/kg & $0.083 \pm 0.01^{\mathrm{a} * \mathrm{C}_{*} \mathrm{~d} \mathrm{~d}_{*} \mathrm{e}_{*} \mathrm{f}_{*}}$ & 82.34 & $0.08 \pm 0.01^{a * c_{*} d_{*} e_{*} f_{*}}$ & 82 \\
\hline AF300mg/kg & $0.43 \pm 0.098^{b *}$ & 8.5 & $0.44 \pm 0.08^{b_{*}}$ & 2.22 \\
\hline AF400mg/kg & $0.38 \pm 0.07^{\mathrm{b} *}$ & 19.12 & $0.43 \pm 0.12^{b *}$ & 4.44 \\
\hline AF500mg/kg & $0.362 \pm 0.09^{\mathrm{b} *}$ & 22.98 & $0.422 \pm 0.09^{\mathrm{b} *}$ & 6.22 \\
\hline AF1000mg/kg & $0.35 \pm 0.06^{\mathrm{b} *}$ & 25.53 & $0.41 \pm 0.05^{b *}$ & 8.89 \\
\hline
\end{tabular}

Values are expressed as Mean \pm S.E.M $(n=6)$, analysis was performed with One-Way ANOVA followed by Tukey test; ${ }^{a}$ compared to control, ${ }^{b}$ to standard drug, ${ }^{c}$ to

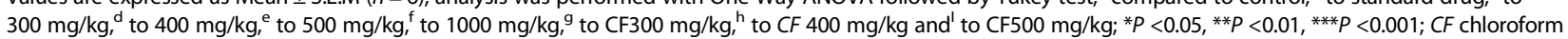
fraction, $M F$ methanol fraction, $A F$ aqueous fraction. Negative controls were treated with the vehicle used for reconstitution ( $2 \% \mathrm{v} / \mathrm{v}$ Tween 80 for the chloroform and methanol fractions or distilled water for the aqueous fraction) orally

Table 3 Effect of the fractions of Croton macrostachyus leaves on castor oil induced intestinal transit in mice

\begin{tabular}{|c|c|c|c|c|}
\hline Dose administered & $\begin{array}{l}\text { Mean length of } \\
\text { small intestine }(\mathrm{cm})\end{array}$ & $\begin{array}{l}\text { Mean Distance traveled by } \\
\text { the charcoal meal }(\mathrm{cm})\end{array}$ & $\begin{array}{l}\text { Peristalsis } \\
\text { index (\%) }\end{array}$ & $\begin{array}{l}\% \text { of } \\
\text { inhibition }\end{array}$ \\
\hline Control & $58.75 \pm 2.48$ & $55.32 \pm 2.78$ & $94.04 \pm 1.74$ & -——- \\
\hline Atropine sulphate 5 mg/kg (i.p) & $60.27 \pm 0.46$ & $18.92 \pm 2.59^{\mathrm{a} * * * c * *}$ & $31.33 \pm 4.22^{\mathrm{a} * * * c * *}$ & 65.78 \\
\hline CF300mg/kg & $57.57 \pm 2.38$ & $41.22 \pm 0.83^{\mathrm{a} * \mathrm{~b}_{* *}}$ & $72.25 \pm 3.42^{\mathrm{a} * \mathrm{~b} * *}$ & 25.49 \\
\hline CF400mg/kg & $58.12 \pm 2.18$ & $31.33 \pm 4.89^{\mathrm{a} * *}$ & $54.56 \pm 8.71^{\mathrm{a**}}$ & 43.36 \\
\hline CF500mg/kg & $61.03 \pm 0.945$ & $29.00 \pm 7.09^{\mathrm{a} * *}$ & $47.37 \pm 11.15^{\mathrm{a**}}$ & 52.42 \\
\hline Control & $60.05 \pm 2.06$ & $56.88 \pm 2.73$ & $94.55 \pm 1.78$ & 一一 \\
\hline Atropine sulphate 5 mg/kg (i.p.) & $63.1 \pm 1.32$ & $24.13 \pm 4.24^{\mathrm{a} * * * c *}$ & $38.71 \pm 7.45^{\mathrm{a} * * * \leftarrow *}$ & 57.58 \\
\hline MF300mg/kg & $61.25 \pm 1.52$ & $43.25 \pm 5.45^{b_{*}}$ & $70.12 \pm 8.38^{\mathrm{b} * \mathrm{e} *}$ & 23.96 \\
\hline MF400mg/kg & $66.28 \pm 2.49$ & $42.87 \pm 5.89$ & $64.59 \pm 8.36$ & 24.63 \\
\hline MF500mg/kg & $63.07 \pm 1.88$ & $25.00 \pm 3.39^{\mathrm{a} * * *}$ & $39.78 \pm 5.66^{\mathrm{a} * * * * *}$ & 56.05 \\
\hline Control & $62.68 \pm 3.54$ & $50.65 \pm 3.88$ & $80.81 \pm 4.02$ & 一一一 \\
\hline Atropine sulphate 5 mg/kg(i.p.) & $61.05 \pm 2.86$ & $18.72 \pm 3.99^{\mathrm{a} * c * \mathrm{~d} *}$ & $30.66 \pm 6.26^{\mathrm{a} * c * \mathrm{~d} *}$ & 63.04 \\
\hline AF300mg/kg & $63.55 \pm 1.47$ & $50.08 \pm 2.65^{b *}$ & $78.8 \pm 6.04^{\mathrm{b*f**}}$ & 1.12 \\
\hline AF400mg/kg & $63.45 \pm 1.54$ & $49.25 \pm 5.76^{\mathrm{b} * f_{*}}$ & $77.62 \pm 8.54^{b * f_{* *}}$ & 2.76 \\
\hline AF500mg/kg & $61.98 \pm 3.69$ & $38.23 \pm 7.74^{f *}$ & $61.68 \pm 11.67$ & 24.5 \\
\hline AF1000mg/kg & $68.00 \pm 1.53$ & $27.45 \pm 2.21^{a_{*} c * d *}$ & $40.53 \pm 3.55^{a_{*} c_{* * *} d_{* *}}$ & 44.26 \\
\hline
\end{tabular}

Values are expressed as Mean \pm S.E.M $(n=6)$, analysis was performed with One-Way ANOVA followed by Tukey test; ${ }^{a}$ compared to control, ${ }^{b}$ to standard drug, ${ }^{c}$ to

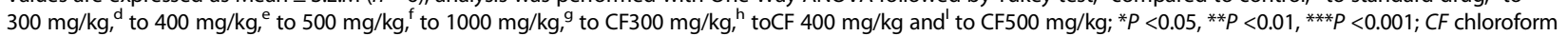
fraction, $M F$ methanol fraction, $A F$ aqueous fraction. Negative controls were treated with the vehicle used for reconstitution ( $2 \% \mathrm{v} / \mathrm{v}$ Tween 80 for the chloroform and methanol fractions or distilled water for the aqueous fraction) orally 


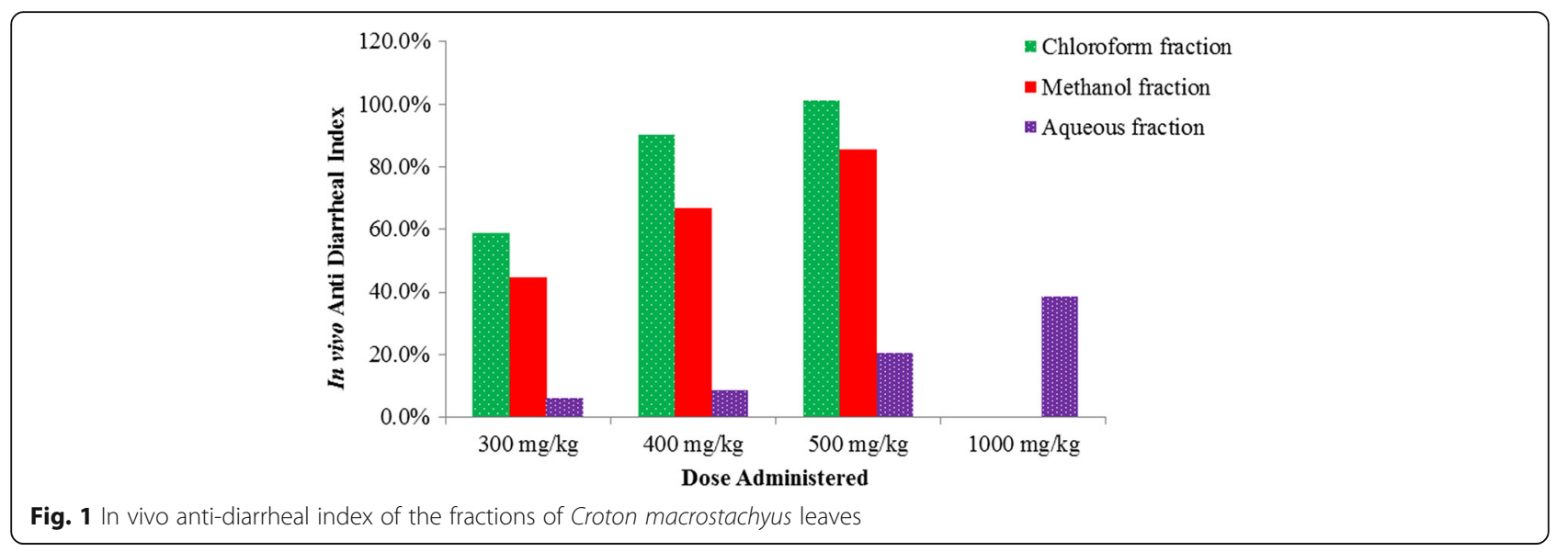

liberated by the action of lipases in the upper part of the small intestine $[37,38]$.

Ricinoleic acid produces local irritation and inflammation of the intestinal mucosa, causing the release of prostaglandins that eventually increase gastrointestinal motility, net secretion of water and electrolytes [39, 40]. This effect could occur due to the capability of ricinoleic acid to activate the $\mathrm{G}$ protein-coupled prostanoid receptor (EP3) on the smooth muscle cell of the intestine [41]. In addition, it forms ricinoleate salts with sodium and potassium in the lumen of the intestine and these salts inhibit sodium-potassium ATPase and increase permeability of the intestinal epithelium, which in turn produces a cytotoxic effect on intestinal absorptive cells [37].

In the castor oil induced diarrheal model, the chloroform (at all tested doses) and methanol fractions (at 400 and $500 \mathrm{mg} / \mathrm{kg}$ ) significantly delayed the time of diarrheal onset, and decreased the frequency of defecation and weight of feces. Moreover, the chloroform fraction showed comparable effect with that of the crude extract in this model [42]. The findings from this study are in line with other studies which show that the chloroform extract of different plants reduced the stool frequency in

Table 4 Preliminary phytochemical screening of solvent fractions of Croton macrostachyus leaves

\begin{tabular}{llll}
\hline Secondary metabolites & Chloroform fraction & $\begin{array}{l}\text { Methanol } \\
\text { fractions }\end{array}$ & $\begin{array}{l}\text { Aqueous } \\
\text { fraction }\end{array}$ \\
\hline Alkaloids & + & + & + \\
Tannins & - & + & + \\
Saponins & - & + & + \\
Terpenoids & + & - & - \\
Steroids & + & - & - \\
Flavonoids & - & + & - \\
Anthraquinones & - & - & - \\
Cardiac Glycosides & - & + & - \\
\hline
\end{tabular}

+ present, - absent a dose-dependent manner [43-45]. In contrast, the aqueous fraction was devoid of any activity at all tested doses. This could possibly suggest the probable localization of the active ingredients in these two fractions.

It is postulated that Non-steroidal anti-inflammatory drugs (NSAIDs) inhibit castor oil -induced prostaglandin production, thereby preventing diarrhoea [46]. Similarly, the aqueous and methylene chloride/methanol extracts from the stem bark of $C$. macrostachyus has been shown to have analgesic and anti-inflammatory activities [20]. It is therefore plausible that the antidiarrheal effect of the active fractions could be attributed to inhibition of castor oil-induced prostaglandin synthesis.

Terpenoids such as abietic acid and steroids like phytosterols have been shown to inhibit production of prostaglandin E2 [47, 48], which are known to play a crucial role in the stimulation of intestinal secretions [49]. Thus, the significant antidiarrheal activity observed in the chloroform fraction could probably be attributed to the presence of these secondary metabolites in the fraction.

Although the chloroform fraction exhibited maximum effect, there was no significant difference in antidiarrheal effects between the chloroform and methanol fractions, indicating that both fractions are active in this model. The present results are concordant with other studies, where the chloroform and methanol fractions displayed comparable inhibition of castor oil induced diarrhea [26, 32].

Despite there appears to be a differential distribution of active constituents in the two fractions, the comparable activity of the two fractions suggests that different secondary metabolites are endowed with antidiarrheal properties.

In the castor oil induced enteropooling test, treatment of mice with different doses of the chloroform and methanol fractions produced a significant decline in the intestinal fluid accumulation. On the contrary, the aqueous fraction did not significantly inhibit castor oil induced intestinal fluid accumulation in all the tested 
doses. In comparison to the crude extract, [42] both chloroform and methanol fraction demonstrated higher effect in this model.

The active metabolite of castor oil (ricinoleic acid) might activate the nitric oxide pathway and induce nitric oxide (NO) dependent gut secretion [50, 51]. A growing body of evidence indicates that phytochemical constituents such as terpenoids [52] and flavonoids [53-55] are implicated in attenuation of NO synthesis. Thus, in contrast to the aqueous fraction, the pronounced inhibition of castor oil induced intestinal fluid accumulation (enteropooling) and the weight of the intestinal content could possibly be linked to the presence of terpenoids (chloroform fraction) and flavonoids (methanol fraction) that increase the reabsorption of electrolytes and water by hindering castor oil mediated NO synthesis. The fact that intestinal fluid accumulation and $\mathrm{Na}+$ secretion induced by castor oil is attenuated by pretreatment of rats with NO synthesis inhibitors [51] reinforces the notion that the anti-enteropooling effect of both fractions could probably be by interfering with the NO pathway.

Alkaloids, which are detected in all fractions, also demonstrated inhibitory effect on NO synthesis [56]. Nevertheless, due to the successive extraction method used in this study, most of the alkaloids could be extracted by the chloroform and methanol, and trace amounts might have remained in the aqueous fraction. Consequently, the phytochemical constituents that could inhibit castor oil induced fluid secretion were either absent or present in undetectable amount in the aqueous fraction, explaining why this fraction had lower antidiarrheal effects.

The antidiarrheal effect of flavonoids has been ascribed to their ability to inhibit intestinal motility and hydro-electrolytic secretion [57-59]. Flavonoids are also able to inhibit the intestinal secretory response induced by prostaglandins E2 [60, 61]. Moreover, the enteric nervous system stimulates intestinal secretion through neurotransmitters such as acetylcholine and vasoactive intestinal peptide. On the other hand, intestinal absorption can be stimulated with alpha two adrenergic agents, enkephalins, and somatostatin $[49,62]$. Secondary metabolites such as flavonoids from plant sources could stimulate alpha two adrenergic receptors in the absorptive cells of the gastrointestinal tract [57]. Hence, in contrast to the aqueous fraction, the significant antisecretory activity of the methanol fraction could probably be related to the existence of flavonoids that in turn stimulate alpha two adrenergic receptors in the enterocytes and promote fluid and electrolyte absorption. However, the chloroform and methanol fractions showed comparable effect in this model despite the better antidiarrheal effect observed in the chloroform fraction. This could perhaps be due to the collective interference of terpenoids and steroids on prostaglandin E2 induced gut secretion $[47,48]$.

Evaluation of intestinal transit, demonstrated a significant reduction in the intestinal propulsive movement of charcoal meal in the chloroform fraction in comparison to the negative control at all the test doses $(300,400$ and $500 \mathrm{mg} / \mathrm{kg}$ body weight). Besides, this fraction showed greater effect in this model as compared to the crude extract in the previous study [42]. This is comparable to other studies, in which the chloroform extract significantly inhibited the distance travelled by charcoal meal [26]. Interestingly, both the methanol fraction $(56.1 \%, p$ $<0.001)$ as well as the aqueous fraction $(44.3 \%, p<0.05)$ produced substantial inhibition of the peristaltic movement of charcoal meal at the higher dose employed in the present study (500 and $1000 \mathrm{mg} / \mathrm{kg}$, respectively). This finding suggests that there is a difference in the potency (chloroform $>>$ methanol $>>$ aqueous fraction) of phytochemical constituents that mediate castor oil induced gastrointestinal motility. The potent action of the chloroform fraction could be ascribed to the synergistic effects of terpenoids and alkaloids to prolong the time for absorption of water and electrolytes through hampering peristaltic movement of the intestine. Indeed, alkaloids [63] and terpenoids $[63,64]$ have been demonstrated to have inhibitory effect on gastrointestinal motility. Although the phytochemical constituents responsible for the antidiarrheal effect are yet to be identified, the amount of phytochemical constituents that are responsible for impeding gastrointestinal motility such as tannins $[65,66]$ and alkaloids [63] appear to increase with dose. This could possibly the reason why significant anti-motility effect was observed at the higher dose of the aqueous fraction. However, in this fraction, significant antidiarrheal effect was not observed in other models with increasing in dose. This might be due to the lack of secondary metabolites such as terpenoids [48], steroids [47] and flavonoids [60, 61] that could inhibit prostaglandin E2 induced fluid secretion in the intestine.

Unlike the castor oil induced and enteropooling diarrheal model, maximum effect was observed with the methanol fraction $(56.1 \%)$ rather than the chloroform fraction $(52.4 \%)$ in charcoal meal test. This could perhaps be linked to the presence of synergistic inhibitory effect of tannins $[38,65,66]$ and flavonoids [57-59] on castor oil induced gastrointestinal motility.

Plants that have tannins in their composition can precipitate proteins of the enterocytes, reducing the peristaltic movements and intestinal secretions $[38,65,66]$. The layers formed by the precipitate of proteins on the mucosal surface of the enterocytes also inhibit the development of microorganisms, thus explaining the antiseptic action of tannins [65]. Based on this fact, the presence of tannins in the methanol fraction might 
provide a clue to further investigate its role for infectious diarrhea, as the present study did not address this issue.

The anti-diarrheal index (ADI) is a measure of the combined effects of the different parameters of diarrhea such as purging frequency, onset of diarrheal stools and intestinal motility [31]. The higher the ADI value the more effective an extract is at curing diarrhea $[67,68]$. The findings revealed that $\mathrm{ADI}$ increased in a dose dependent manner for all the fractions suggesting the dose dependency of this parameter. The chloroform fraction showed the highest ADI value as compared to the other fractions, reinforcing the notion that this fraction is endowed with the best antidiarrheal activity among all the solvent fractions. Conversely, the aqueous fraction, which had little or no antidiarrheal activity in most of the models, exhibited the lowest ADI, pointing to the fact that ADI is a useful parameter in ranking antidiarrheal agents.

\section{Conclusion}

The present study revealed that the chloroform and methanol fractions of $C$. macrostachyus leaves possessed significant anti-diarrheal activity. Nevertheless, the aqueous fraction showed only significant anti-motility effect at the higher dose $(1000 \mathrm{mg} / \mathrm{kg})$ employed in the study. The antidiarrheal activities of these fractions could be attributed to the presence of bioactive agents, which are either non-polar or semi polar, including, among others, tannins, alkaloids, saponins, flavonoids, steroids, and terpenoids that act individually or collectively. Hence, further studies that aim to isolate the active principle (s) or elucidating the possible mechanism of action should use either fraction.

\section{Abbreviations}

ADI: Anti-diarrheal index; NO: Nitric oxide; NSAIDs: Non- steroidal antiinflammatory drugs

\section{Acknowledgments}

The authors would like to acknowledge Addis Ababa and Ambo University for their material and financial support for this project.

\section{Funding}

The projected was conducted under the financial support of Addis Ababa University.

\section{Availability of data and materials}

The datasets analyzed during the current study available from the corresponding author on reasonable request.

\section{Authors' contributions}

AD conducted the actual study and the statistical analysis. AD, EE and WS were involved in developing the idea, designing of the study and the write up of the manuscript. All authors approved the submitted version of the manuscript.

\section{Competing interests}

The authors declare that they have no competing interest.

\section{Consent for publication}

"Not applicable" in this section.

\section{Ethics approval}

Ethical clearance was approved by Institutional Ethics Committee of College of Health Sciences of Addis Ababa University under the reference number EC/20/2013 in $19^{\text {th }}$ October 2013 to conduct the study in animal model. Apart from that, all possible steps were taken to avoid animal suffering at each stage of the experiment.

\section{Author details}

${ }^{1}$ Department of Pharmacy, College of Medicine and Health Sciences, Ambo University, P.O, Box 19, Ambo, Ethiopia. ${ }^{2}$ Department of Pharmacology and Clinical Pharmacy, College of Health Sciences, School of Pharmacy, Addis

Ababa University, P.O. Box 1176, Addis Ababa, Ethiopia.

Received: 6 February 2016 Accepted: 9 September 2016

Published online: 29 September 2016

\section{References}

1. CDC. Global Diarrhea Burden [Internet]. 2012 [cited 2013 Sep 7]. Available from: http://www.cdc.gov/healthywater/global/diarrhea-burden.html.

2. WHO. Diarrhoeal Disease [Internet]. 2012 [cited 2013 Sep 7]. Available from: http://www.who.int/mediacentre/factsheets/fs330/en/\#content. Accessed 7 Sept 2013.

3. Fischer Walker CL, Perin J, Aryee MJ, Boschi-Pinto C, Black RE. Diarrhea incidence in low- and middle-income countries in 1990 and 2010: a systematic review. BMC Public Health [Internet]. 2012;12(1):220. Available from: http://www.pubmedcentral.nih.gov/articlerender.fcgi?artid= 3323412\&tool=pmcentrez\&rendertype=abstract.

4. Fischer Walker CL, Rudan I, Liu L, Nahir H, Theodoratou E, Bhutta ZA, et al. Global burden of childhood pneumonia and diarrhoea. Lancet. 2013;381(9875):1405-16.

5. Awoke W. Prevalence of childhood illness and mothers'/caregivers' care seekingbehavior in Bahir Dar, Ethiopia: a descriptive community based cross sectional study. Open J Prev Med. 2013;3(2):155-9.

6. Dessalegn M, Kumie A, Tefera W. Predictors of under-five childhood diarrhea: Mecha District, West Gojam, Ethiopia. Ethiop J Health Dev. 2011;25(3):192-200.

7. Mamo A, Hailu A. Assessment of prevalence and related factors of diarrheal diseases among under-five year's children in Debrebirehan Referral Hospital, Debrebirehan Town, North Shoa Zone, Amhara Region, Ethiopia. Open Access Libr J [Internet]. 2014;1:1-14. Available from: http://www.oalib.com/ articles/3000873\#.V-ZizPITLrd.

8. Mohammed S, Tilahun M, Tamiru D. Morbidity and associated factors of diarrheal diseases among under five children in Arba-Minch District, Southern Ethiopia. Sci J Public Health. 2013;1(2):102-6.

9. Kim HS. Do not put too much value on conventional medicines. J Ethnopharmacol. 2005;100(1-2):37-9.

10. World Health Organization. General guidelines for methodologies on research and evaluation of traditional medicine. WHO-Geneva [Internet]. 2000;1:1-74. Available from: http://apps.who.int/medicinedocs/en/d/Jwhozip42e/.

11. Etana B, Demissew S, Asfaw Z. Ethnobotanical study of traditional medicinal plants of Goma Wereda, Jima zone of Oromia region, Ethiopia. Unpublished Masters Thesis. Addis Ababa: Addis Ababa University Institutional Repository; 2010. Available from: http://etd.aau.edu.et/handle/123456789/317.

12. Teklehaymanot T, Giday M. Ethnobotanical study of medicinal plants used by people in Zegie Peninsula, Northwestern Ethiopia. J Ethnobiol Ethnomed. 2007:3:12.

13. Flatie T, Gedif T, Gebre-Mariam T, Asres K. Ethnomedical survey of Berta ethnic group Assosa Zone, Benishangul-Gumuz Regional State, mid-west Ethiopia. J Ethnobiol Ethnomed. 2009;5:14

14. Orwa C, Mutua A, Kindt R, Jamnadass R, Anthony S. Agroforestree Database: a tree reference and selection guide version 4.0. 2009. p. 1-5. http://www. worldagroforestry.org/af/treedb/).

15. Salatino A, Salatino MF, Negri G. Traditional uses, Chemistry and Pharmacology of Croton species (Euphorbiaceae). J Braz Chem Soc. 2007:18(1):11-33.

16. Mesfin F, Demissew S, Teklehaymanot T. An ethnobotanical study of medicinal plants in Wonago Woreda, SNNPR, Ethiopia. J Ethnobiol Ethnomed. 2009;5:28.

17. Tefera M, Geyid A, Debella A. In vitro anti-Neisseria gonorrhoeae activity of Albizia gummifera and Croton macrostachyus. Pharmacologyonline. 2012;1(SPL. 1):75-83.

18. Bantie L, Assefa S, Teklehaimanot T, Engidawork E. In vivo antimalarial activity of the crude leaf extract and solvent fractions of Croton 
macrostachyus Hocsht. (Euphorbiaceae) against Plasmodium berghei in mice. BMC Complement Altern Med. 2014;14:79.

19. Gemechu A, Giday M, Worku A, Ameni G. In vitro anti-mycobacterial activity of selected medicinal plants against Mycobacterium tuberculosis and Mycobacterium bovis Strains. BMC Complement Altern Med. 2013;13:291.

20. Kamanyi A, Mbiantcha M, Nguelefack TB, Ateufack G, Watcho P, Ndontsa BL, et al. Anti-nociceptive and anti-Inflammatory activities of extracts from the stem bark of Croton macrostachyus (Euphorbiaceae) in mice and rats. J Complement Integr Med. 2009;6(1):1-17.

21. Ngo Bum E, Ngah E, Ngo Mune RM, Ze Minkoulou DM, Talla E, Moto FC, et al. Decoctions of Bridelia micrantha and Croton macrostachyus may have anticonvulsant and sedative effects. Epilepsy Behav. 2012;24(3):319-23.

22. Gelaw H, Adane L, Tariku Y, Hailu A. Isolation Of crotepoxide from berries of Croton macrostachyus and evaluation of its anti-leishmanial activity. J Pharmacogn Phytochem. 2012;1(4):15-25.

23. Umer S, Tekewe A, Kebede N. Antidiarrhoeal and antimicrobial activity of Calpurnia aurea leaf extract. BMC Complement Altern Med. 2013;13:21.

24. National Research Council. Guide for the care and use of laboratory animals. 8th ed. Washington: The National Academies Press; 2011.

25. Rahman A, Hasan SN, Sampad KS, Das AK. Antinociceptive, anti diarrheoal and cytotoxic activities of Rhizophora mucronata Lamk. Pharmacologyonline. 2011;1:921-9

26. Zavala-Mendoza D, Alarcon-Aguilar FJ, Perez-Gutierrez S, Escobar-Villanueva MC, Zavala-Sanchez MA. Composition and antidiarrheal activity of Bidens odorata Cav. Evid Based Complement Alternat Med. 2013;1:1-7.

27. Dosso K, Nguessan BB, Bidie AP, Gnangoran BN, Meite N, Nguessan D, et al. Antidiarrhoeal activity of an ethanol extract of the stem bark of Piliostigma reticulatum (Caesalpiniaceae) in rats. Afr J Tradit Complement Altern Med. 2012;9(2):242-9.

28. Mamza UT, Sodipo OA, Khan IZ, Wampana B. Evaluation of antidiarrhoeal activity of ethanolic extract from the leaves of Phyllanthus amarus (Euphorbiacea). Int J Green Herb Chem. 2014;3(1):171-8.

29. Than A, Kulkarni HJ, Hmone W, Tha SJ. Anti-diarrhoeal efficacy of some Burmese indigenous drug formulations in experimental diarrhoeal test models. Int J Crude Drug Res. 1989;27(4):195-200.

30. Chitme HR, Chandra R, Kaushik S. Study of antidiarrhoeal activity of Calotropis gigantea R.Br. in experimental animals. J Pharm Pharmceut Sci. 2004;7(1):70-5.

31. Hussain Z, Amresh G, Singh S, Rao CV. Antidiarrheal and antiulcer activity of Amaranthus spinosus in experimental animals. Pharm Biol. 2009;47(10):932-9.

32. Islam AM, Uddin ME, Chowdhury AU, Rahman M, Habib R, Rahman A. In vivo antidiarrheal and cytotoxic potential of different fractions of Pandanus foetidus Leaves. Am J Biomed Sci. 2013:5(3):208-16.

33. Ayoola GA, Coker HAB, Adesegun SA, Adepoju-bello AA, Obaweya K, Ezennia EC, et al. Phytochemical screening and antioxidant activities of some selected medicinal plants used for malaria therapy in Southwestern Nigeria. Trop J Pharm Res. 2008;7(3):1019-24

34. OECD. OECD guidelines for the testing of Chemicals. Test. 2004;(October):1-21.

35. Akter S, Sarker A, Hossain S. Antidiarrhoeal activity of rind of Punica granatum. Int Curr Pharm J. 2013;2(5):101-4.

36. Dahiru D, Sini JM, John-Africa L. Antidiarrhoeal activity of Ziziphus mauritiana root extract in rodents. Afr J Biotechnol. 2006;5(10):941-5.

37. Komal, Kumar S, Rana AC. Herbal apporaches for diarrhea: a review. Int Res J Pharm. 2013:4(1):31-8

38. Tripathi K. Essentials of medical pharmacology. 8th ed. New Delhi: Jaypeeb Brothers Medicals Publishers (P) Ltd; 2008.

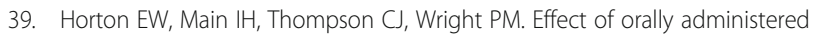
prostaglandin $\mathrm{E} 1$ on gastric secretion and gastrointestinal motility in man. Gut. 1968;9(6):655-8.

40. Robert A, Nezamis JE, Lancaster C, Hanchar AJ, Klepper MS. Enteropooling assay: a test for diarrhea produced by prostaglandins. Prostaglandins. 1976;11(5):809-28.

41. Tunaru S, Althoff TF, Nusing RM, Diener M, Offermanns S. Castor oil induces laxation and uterus contraction via ricinoleic acid activating prostaglandin EP3 receptors. Proc Natl Acad Sci U S A. 2012;109(23):9179-84.

42. Busa Z, Engidawork E. Evaluation of in vivo anti-diarrheal activity of $80 \%$ methanolic extract of the Leaves of Croton macrostachyus Hochst. (Euphorbiaceae) in Rats. Unpublished Master. Addis Ababa: Addis Ababa University Institutional Repository; 2014. Available from: http://etd.aau.edu. et/handle/123456789/6094

43. Billah MM, Khatun $\mathrm{H}$, Parvin S, Islam E, Islam SM, Mia AA, et al. Antibacterial, antidiarrhoeal, and cytotoxic activities of methanol extract and its fractions of Caesalpinia bonducella (L.) Roxb leaves. BMC Complement Altern Med. 2013;13(1):101.

44. Karthik P, Kumar RN, Amudha P. Anti diarrheal activity of the chloroform extract of Cayratia pedata Lam in albino wistar rats. Pharmacologyonline. 2011;2:69-75

45. Mazumder R, Bhattacharya S, Mazumder A, Pattnaik AK, Tiwary PM, Chaudhary S. Antidiarrhoeal evaluation of Aegle marmelos (Correa) Linn. root extract. Phytother Res. 2006;20(1):82-4.

46. Awouters F, Niemegeers CJ, Lenaerts FM, Janssen PA. Delay of castor oil diarrhoea in rats: a new way to evaluate inhibitors of prostaglandin biosynthesis. J Pharm Pharmacol. 1978;30(1):41-5.

47. Awad AB, Toczek J, Fink CS. Phytosterols decrease prostaglandin release in cultured P388D1/MAB macrophages. Prostaglandins Leukot Essent Fatty Acids. 2004;70(6):511-20.

48. Fernandez MA, Tornos MP, Garcia MD, De las Heras B, Villar AM, Saenz MT. Anti-inflammatory activity of abietic acid, a diterpene isolated from Pimenta racemosa var. grissea. J Pharm Pharmacol. 2001;53(6):867-72.

49. Bern MJ, Sturbaum CW, Karayalcin SS, Berschneider HM, Wachsman JT, Powell D. Immune system control of rat and rabbit colonic electrolyte transport. Role of prostaglandins and enteric nervous system. J Clin Invest. 1989:83(6):1810-20.

50. Mascolo N, Izzo AA, Autore G, Barbato F, Capasso F. Nitric oxide and castor oil-induced diarrhea. J Pharmacol Exp Ther [Internet]. 1994;268(1):291-5. Available from: http://www.scopus.com/inward/record.url?eid=2-s2.00028158420\&partnerID=tZOtx3y1.

51. Mascolo N, Izzo AA, Barbato F, Capasso F. Inhibitors of nitric oxide synthetase prevent castor-oil-induced diarrhoea in the rat. $\mathrm{Br} J$ Pharmacol. 1993;108(4):861-4

52. Jang DS, Min HY, Jeong YH, Lee SK, Seo EK. Di- and sesqui-terpenoids isolated from the pods of Sindora sumatrana and their potential to inhibit lipopolysaccharide-induced nitric oxide production. Arch Pharm Res. 2004; 27(3):291-4.

53. Kim HK, Cheon BS, Kim YH, Kim SY, Kim HP. Effects of naturally occurring flavonoids on nitric oxide production in the macrophage cell line RAW 264.7 and their structure-activity relationships. Biochem Pharmacol. 1999; 58(5):759-65.

54. Kim SJ, Park H, Kim HP. Inhibition of nitric oxide production from lipopolysaccharide-treated RAW 264.7 cells by synthetic flavones: structureactivity relationship and action mechanism. Arch Pharm Res. 2004;27(9):937-43.

55. Messaoudene D, Belguendouz H, Ahmedi ML, Benabdekader T, Otmani F, Terahi M, et al. Ex vivo effects of flavonoids extracted from Artemisia herba alba on cytokines and nitric oxide production in Algerian patients with Adamantiades-Behcet's disease. J Inflamm. 2011:8:35.

56. Kondo Y, Takano F, Hojo H. Inhibitory effect of bisbenzylisoquinoline alkaloids on nitric oxide production in activated macrophages. Biochem Pharmacol. 1993;46(11):1887-92.

57. Di Carlo G, Autore G, Izzo AA, Maiolino P, Mascolo N, Viola P, et al. Inhibition of intestinal motility and secretion by flavonoids in mice and rats: Structure activity relationships. J Pharm Pharmacol. 1993:45(12):1054-9.

58. Galvez J, Crespo ME, Jimenez J, Suarez A, Zarzuelo A. Anti-diarrhoeic activity of quercitrin in mice and rats. J Pharm Pharmacol. 1993;45(2):157-9.

59. Rao VS, Santos FA, Sobreira TT, Souza MF, Melo CL, Silveira ER. Investigations on the gastroprotective and antidiarrhoeal properties of ternatin, a tetramethoxyflavone from Egletes viscosa. Planta Med. 1997;63(2):146-9.

60. Hamalainen $M$, Nieminen $R$, Asmawi MZ, Vuorela $P$, Vapaatalo $H$, Moilanen E. Effects of flavonoids on prostaglandin E2 production and on COX-2 and mPGES1 expressions in activated macrophages. Planta Med. 2011;77(13):1504-11.

61. Sanchez de Medina F, Galvez J, Gonzalez M, Zarzuelo A, Barrett KE. Effects of quercetin on epithelial chloride secretion. Life Sci. 1997:61(20):2049-55.

62. Fedorak RN, Field M, Chang EB. Treatment of diabetic diarrhea with clonidine. Ann Intern Med. 1985;102(2):197-9.

63. Palombo EA. Phytochemicals from traditional medicinal plants used in the treatment of diarrhoea: modes of action and effects on intestinal function. Phytother Res. 2006;20(9):717-24.

64. Maciel MA, Pinto AC, Arruda AC, Pamplona SG, Vanderlinde FA, Lapa AJ, et al. Ethnopharmacology, phytochemistry and pharmacology: a successful combination in the study of Croton cajucara. J Ethnopharmacol. 2000;70(1):41-55.

65. Almeida CE, Karnikowski MG, Foleto R, Baldisserotto B. Analysis of antidiarrhoeic effect of plants used in popular medicine. Rev Saude Publica. 1995;29(6):428-33. 
66. Yadav AK, Tangpu V. Antidiarrheal activity of Lithocarpus dealbata and Urena lobata extracts: therapeutic implications. Pharm Biol. 2007;45(3):223-9.

67. Ching FP, Ek O, Ozolua Rl, Okpo SO. Antidiarrhoeal activities of aqueous extract of Stereospermum kunthianum (Cham, Sandrine Petit) stem bark in rodents. Afr J Biotechnol. 2008;7(9):1220-5.

68. Prasad SK, Laloo D, Kumar R, Sahu AN, Hemalatha S. Antidiarrhoeal evaluation of rhizomes of Cryptocoryne spiralis Fisch. ex Wydler: antimotility and antisecretory effects. Indian J Exp Biol. 2014;52(2):139-46.

Submit your next manuscript to BioMed Central and we will help you at every step:

- We accept pre-submission inquiries

- Our selector tool helps you to find the most relevant journal

- We provide round the clock customer support

- Convenient online submission

- Thorough peer review

- Inclusion in PubMed and all major indexing services

- Maximum visibility for your research

Submit your manuscript at www.biomedcentral.com/submit 